\title{
An Analysis of Anomalies Split To Examine Efficiency in the Saudi Arabia Stock Market
}

\author{
Mohammed A. Hokroh \\ MBA (Finance), University of Leicester, Business System Analyst \\ Phone: +966 0568570987 E-mail: Mohammed.Hokroh@Gmail.com
}

Received: June 05, 2013 Accepted: June 18, 2013 DOI: 10.5296/ijafr.v3i1.3850

\begin{abstract}
This research continues the investigation of Hokroh (2013) whose work examined the Saudi Stock Market (SSM) efficiency before and after the formation of Tadawul Company (the entity responsible for operating the SSM). The SSM stock price returns index before Tadawul (January $1^{\text {st }} 2007$ to March $18^{\text {th }} 2007$ ) and after Tadawul (March $19^{\text {th }} 2007$ to May $29^{\text {th }} 2007$ ) in addition to 52 days split of returns from 5/30/2007 to 11/11/2008 were examined to test if anomalies split assumption holds over time. The data was analyzed using: regression, abnormal returns calculation, T-statics test and correlation. The results indicate that the SSM has become informationally more efficient after the formation of "Tadawul" and that the SSM adjust slowly to market information.
\end{abstract}

Keywords: Auditing, Job satisfaction, Gender, Job attitude 


\section{Macrothink \\ International Journal of Accounting and Financial Reporting \\ ISSN 2162-3082 \\ 2013, Vol. 3, No. 1}

\section{Introduction}

\section{A. The Saudi Stock Market:}

The Saudi Stock Market (SSM) has history full of changes, restructure and development. Since its establishment in 1934, it has gone through various regulatory changes and emerged gradually until today. (Hokroh 2013) The SSM has attracted researchers to investigate its efficiency. Building on Fama efficiency theory, scholars used different techniques and test statistics to examine the efficiency assumption. However, the event study techniques have never been attempted so far. I am not aware of any research used the event study methods to test for the SSM efficiency.

\section{B. Event Studies:}

The development work of this research is influenced by Fama (1998) who pointed out that when scholars try to examine market efficiency through testing price returns for a long period of time, they are faced with a dilemma. The dilemma is that most of the correlation and run-tests will conclude inefficiency. Fama pointed out that this is not a valid conclusion and recommended event studies as alternative methodology. Event studies are statistical tools and techniques that are used to measure stock prices reaction to market events and news. Fama (1998) point out that if an even anomalies split between underreaction and overreaction can be observed, then they cannot be attributed to chance and are consistent with the efficiency theory.

\section{Continue of Hokroh (2013) Work:}

This research continues the investigation of Hokroh (2013) whose work examined the SSM efficiency before and after the introduction of Tadawul Company (the entity responsible for operating the SSM) but could not confirm if the SSM has become efficient or not. Hokroh (2013) advised more work to be done on the subject. His recommendations are discussed in the literature review section.

\section{Literature review}

\section{Previous work:}

There have been few studies that discussed the efficiency theory in the SSM (Butler et.al. 1992, Al-Razeen 1997, Khababa 1998, Onour 2004, Al- Abdulqader et.al. 2007, Hokroh 2013) but produced varying conclusions. Most of the studies conducted on the SSM efficiency have analyzed different samples taken from different periods of a market that has gone through various reformations (Hokroh 2013). For more details on previous work refer to Hokroh (2013). Previous work, except Hokroh (2013), was done before the emergence of the Tadawul Company which is considered the most major recent market restructure. Hokroh (2013) study tested the SSM efficiency before and after "Tadawul" and could not confirm if the SSM has improved after "Tadawul" formation. Hokroh (2013) performed two statistical techniques (autocorrelation and run-test) on the SSM index from January $1^{\text {st }} 2007$ to March $18^{\text {th }} 2007$ (before Tadawul) and from March $19^{\text {th }} 2007$ to May $29^{\text {th }} 2007$ (after Tadawul). The results showed efficiency improvement after Tadawul. However, this "efficiency improvement" has 


\section{Mll Macrothink}

International Journal of Accounting and Financial Reporting ISSN 2162-3082

significantly overturned as time passes. A growing literature relates this phenomenon to market slow adjustment to information but Fama challenges this inference (Hokroh 2013). For long term returns, Fama (1998) point out that if an even anomalies split between underreaction and overreaction can be observed, then they cannot be attributed to chance and are consistent with the efficiency theory. The analysis of anomalies split between underreaction and overreaction has never been attempt in previous work on the SSM. Hokroh (2013) recommended that further research should consider analysis underreaction and overreaction split before and after "Tadawul" to examine "efficiency". Accordingly, this research will take a further step to investigate Fama's argument, based on Hokroh (2013) work, and will examine the SSM efficiency before and after "Tadawul". The data collected in Hokroh (2013) will be analyzed to identify anomalies split. This research will examine the anomalies split through four main steps: 1) regression, 2) calculating abnormal returns, 3) T-statics test and 4) correlation. The data collection process and analysis approach is shown in details in the methodology section.

\section{Methodology}

\section{A. Data Collection:}

The empirical work of this research is based on Hokroh (2013). The SSM stock price returns before Tadawul (January $1^{\text {st }} 2007$ to March $18^{\text {th }}$ 2007) and after Tadawul (March $19^{\text {th }} 2007$ to May $29^{\text {th }}$ 2007) were examined (52 days before Tadawul and 52 days After Tadawul). Furthermore, another 52 days split of returns data from 5/30/2007 to 11/11/2008 were also examined to test if anomalies split assumption holds over time. Accordingly, the collected data (returns) were divided into 9 periods (data sets) with 52 days for each period. The total number of observation captured was 468 observations.

The SSM daily stock price returns index included all the daily closing price for all shares traded from 11:00 a.m. to 3:30 p.m. (Hokroh 2013). All data was collected from the Tadawul Company's website (http://www.tadawul.com.sa) using the websites' historical database search engine (Hokroh 2013).

\section{B. Expected Returns:}

The first step, after the data collection, was to get the respective expected return for each actual return using liner regression equations. The assumption of the regression equations is that the expected returns will not significantly change before and after Tadawul. Thus, the price returns after Tadawul (dependent variable) will be based on price returns before Tadawul (independent Variable) and vise-versa. The regression equations are shown in table 1 and 2. 


\begin{tabular}{|c|c|c|c|c|c|c|}
\hline \multicolumn{7}{|c|}{ Coefficients $^{a}$} \\
\hline & \multirow[b]{2}{*}{ Model } & \multicolumn{2}{|c|}{$\begin{array}{c}\text { Unstandardized } \\
\text { Coefficients }\end{array}$} & \multirow{2}{*}{$\begin{array}{c}\begin{array}{c}\text { Standardized } \\
\text { Coefficients }\end{array} \\
\text { Beta }\end{array}$} & \multirow[b]{2}{*}{$\mathrm{t}$} & \multirow[b]{2}{*}{ Sig. } \\
\hline & & $\mathrm{B}$ & Std. Error & & & \\
\hline \multirow{2}{*}{1} & (Constant) & 9606.956 & 1723.184 & & 5.575 & .000 \\
\hline & Actual return (after Tadawaul) & -.230 & .222 & -.145 & -1.036 & .305 \\
\hline \multicolumn{7}{|c|}{ a. Dependent Variable: Actual return (before Tadawaul) } \\
\hline \multicolumn{7}{|c|}{ Expected Return before Tadawul = 9606.956- .230 (Actual return (beforeTadawaul)) } \\
\hline
\end{tabular}

Table 1: Expected returns before Tadawul

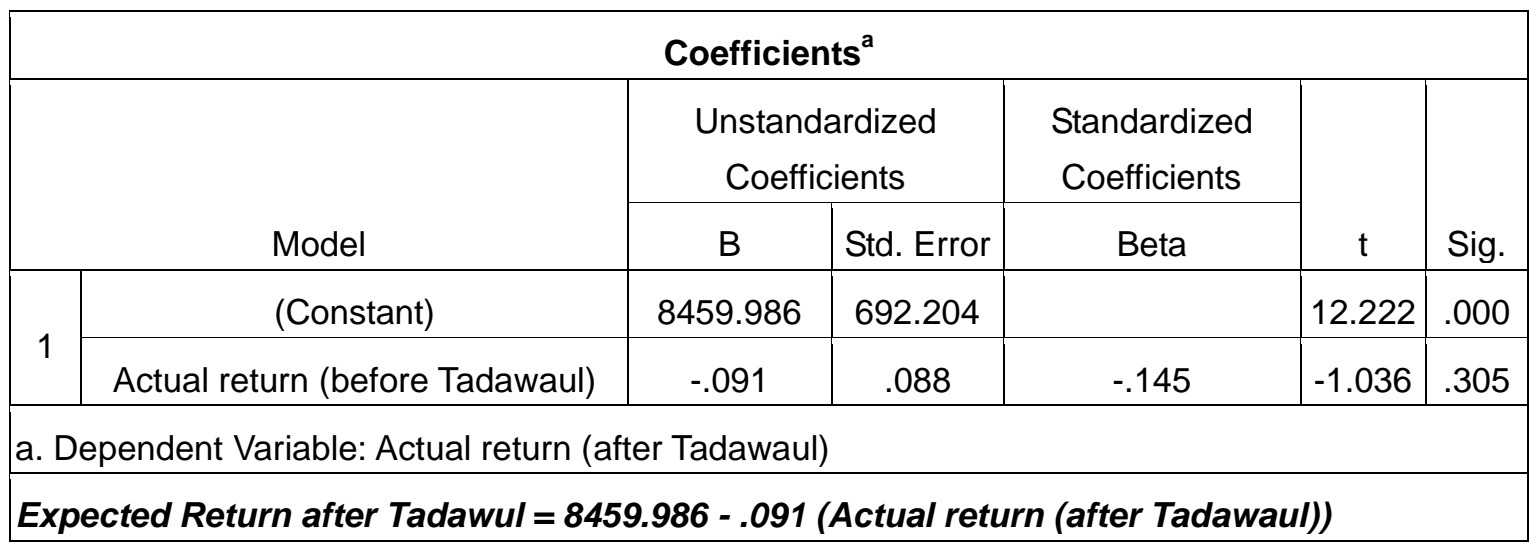

Table 2: Expected returns after Tadawul

The regression equations were applied on the SSM daily stock price returns to get their respective expected returns. The expected returns were computed for each of the 9 periods of the data sets. The regression equation outcomes are illustrated in tables 3 and 4.

\section{Abnormal Returns:}

After getting the respective expected returns, I calculated the abnormal returns. The abnormal returns are defined as the difference between the actual and expected returns. They can be computed using the below formula:

\section{Abnormal Return = Actual Return - Expected Return}

The results of the computation are shown in tables 3 and 4 .

\section{T-Statistics:}

The $t$-statistics was applied on the Delta $(\Delta)$ of each period of the 9 data sets. The t-test will be used to examine if there is a significant difference between the mean of the Deltas $(\Delta)$ of each data set. Thus, two hypotheses are derived:

$H_{0}=0$ (there is no difference between the means of each data set)

$H_{1} \neq 0$ (there is a difference between the means of each data set) 


\section{E. Correlation:}

The final step in my examination was to test the correlation between Delta $(\Delta)$ values of each data set to see if a trend can be drawn. This further step was taken to examine if the SSM participants react slowly to market information or is it only the split assumption that is valid.

$H_{0}=0$ (there is no sequence in Delta $(\Delta)$ values)

$H_{1} \neq 0$ (there is a sequence in Delta $(\Delta)$ values)

\section{Results and Findings:}

\section{A. Regression Equations Results:}

The regression equations outcome is detailed in table 3 and 4 . 


\section{MIN Macrothink}

International Journal of Accounting and Financial Reporting

ISSN 2162-3082

2013, Vol. 3, No. 1

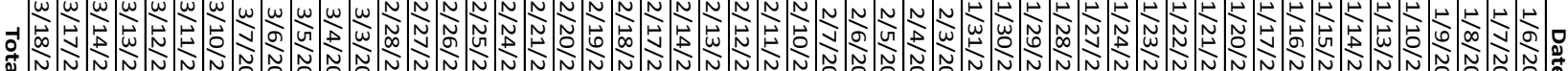

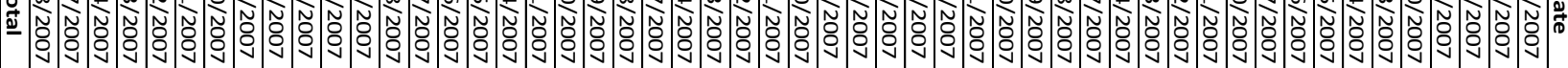

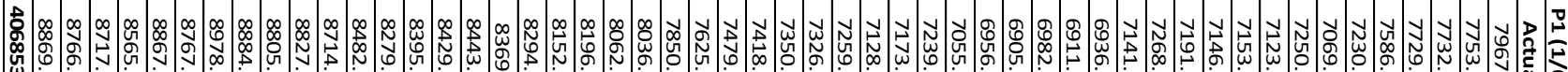

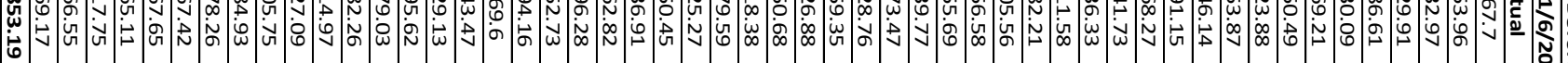

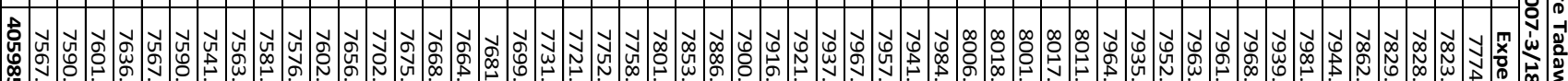

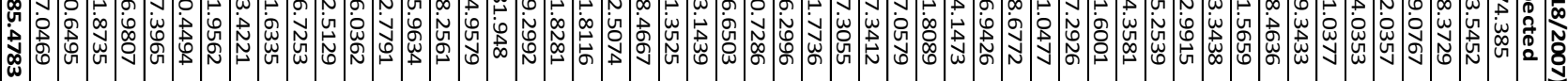

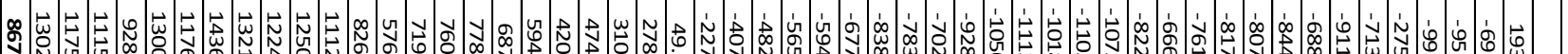

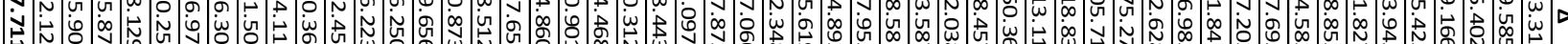

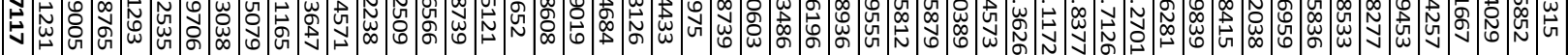

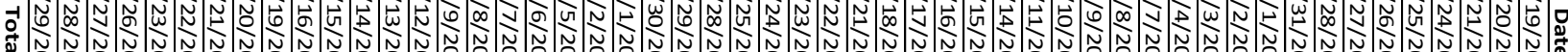

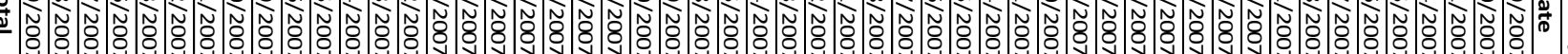

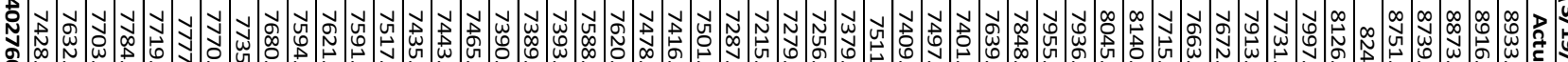

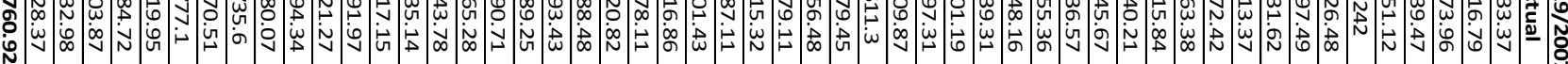

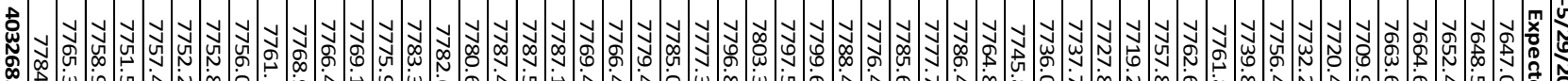

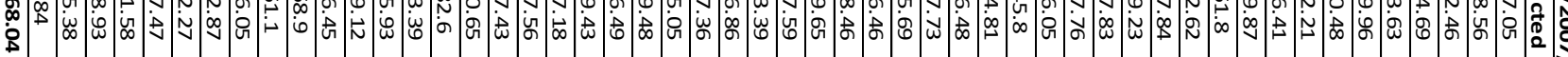

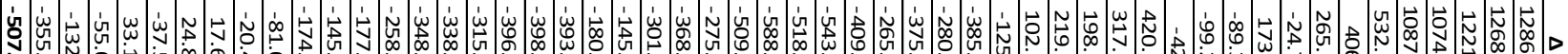

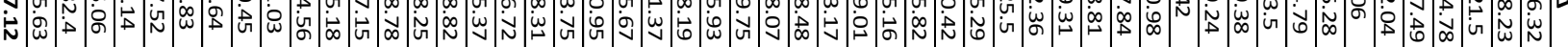

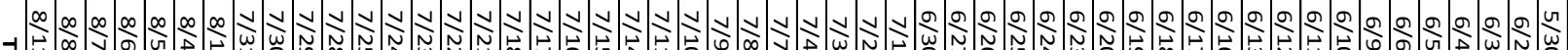

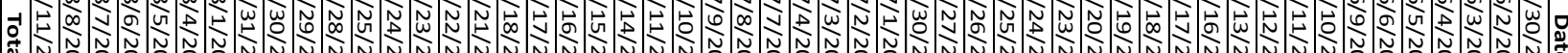
业

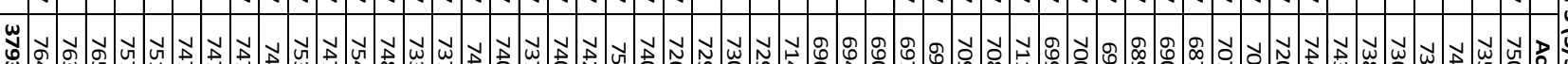

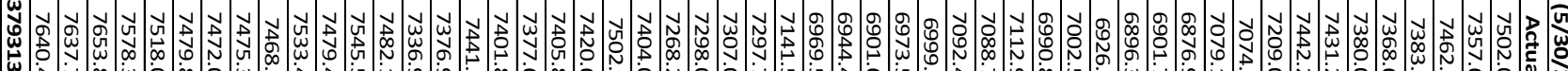

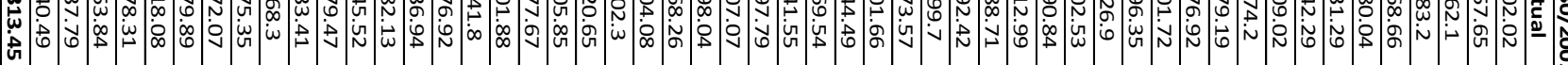

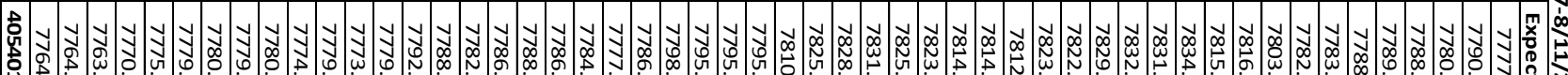

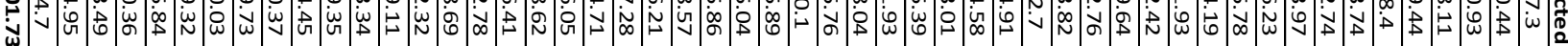

\section{西}

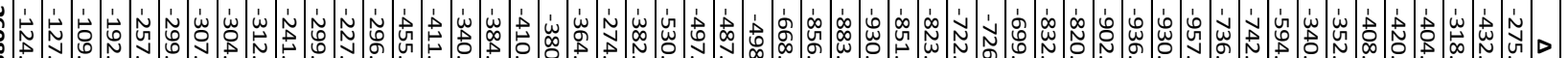

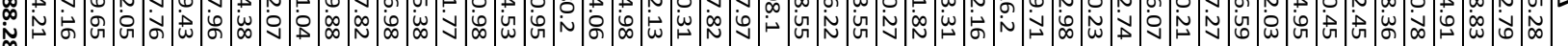

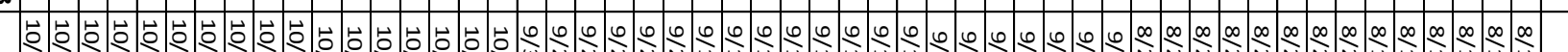

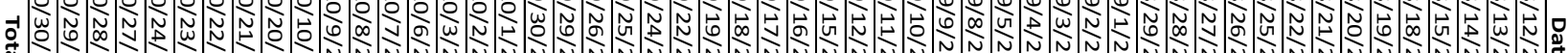

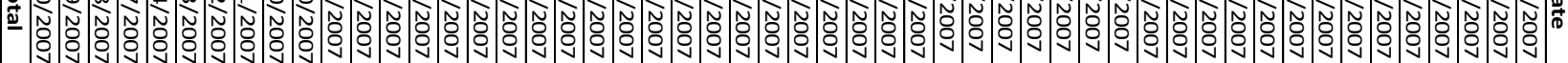

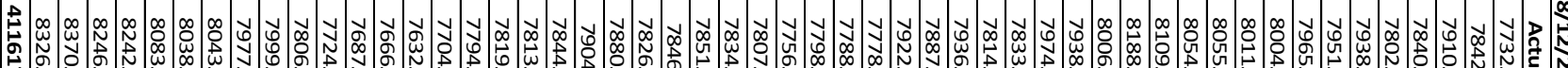

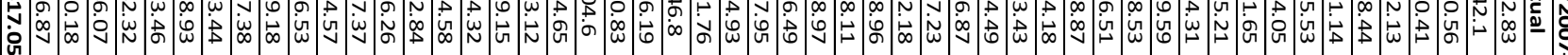

b y y y y y y y y y y y y y y y y y y

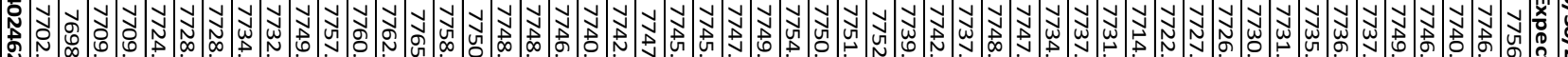

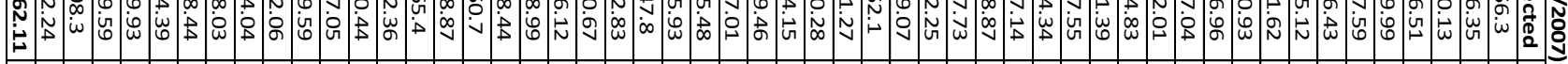

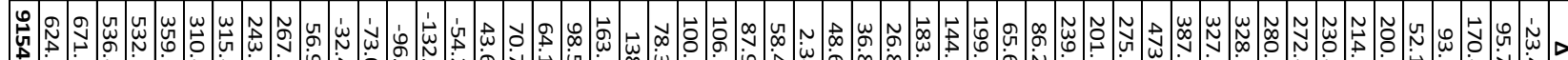

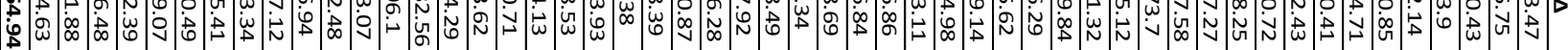

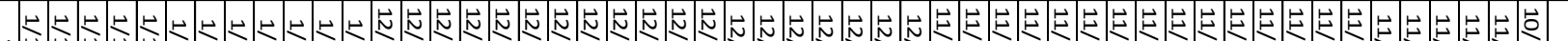

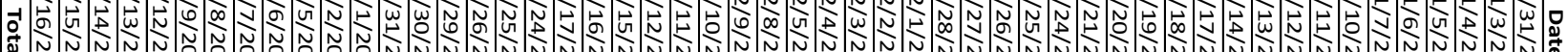

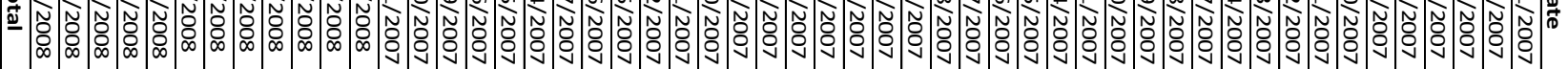

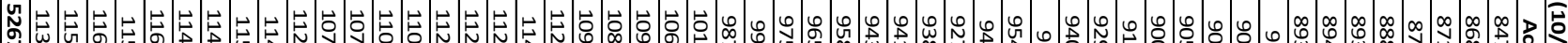

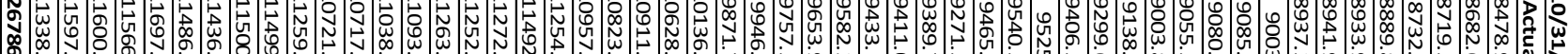

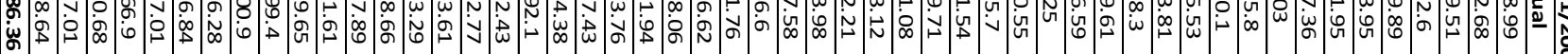

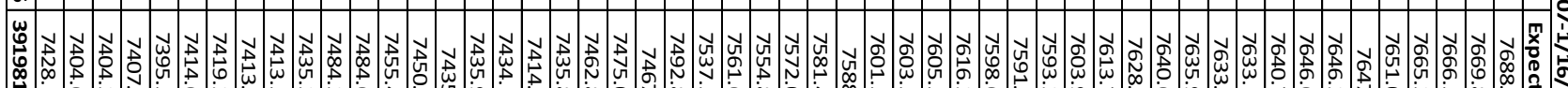

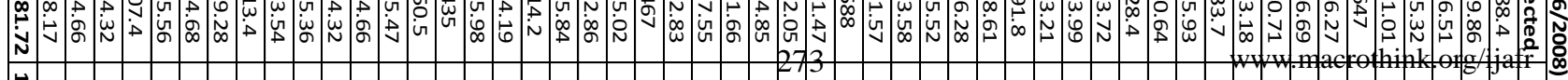




\section{Macrothink}

International Journal of Accounting and Financial Reporting

ISSN 2162-3082

2013, Vol. 3, No. 1

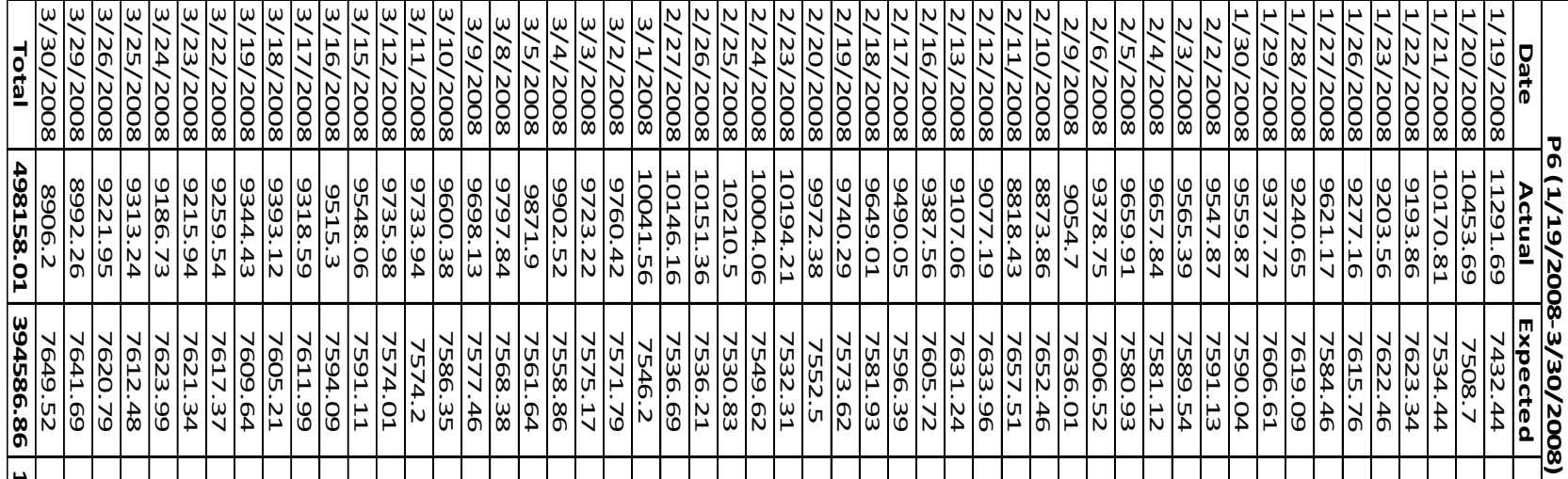

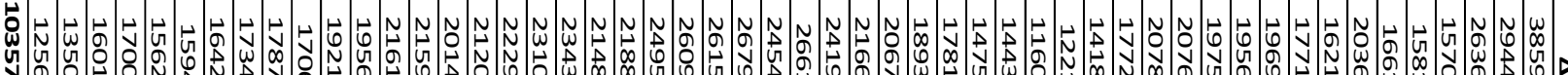

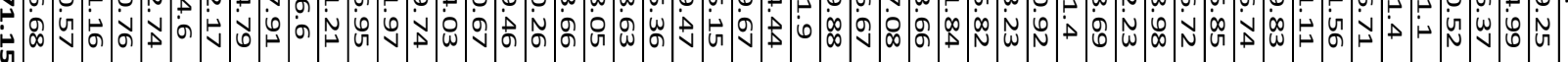

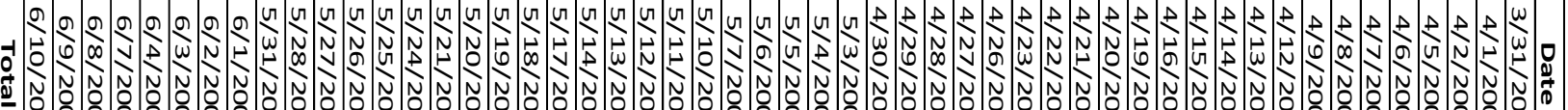

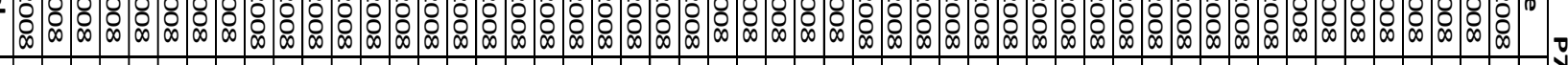

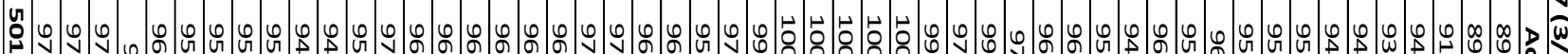

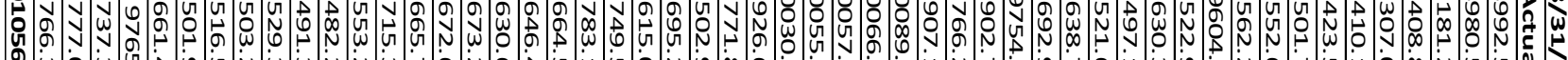

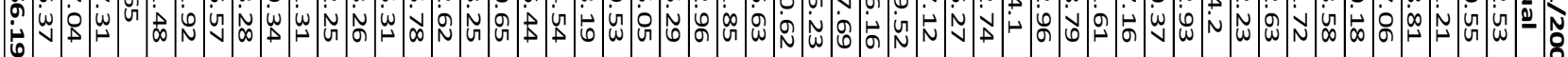

w

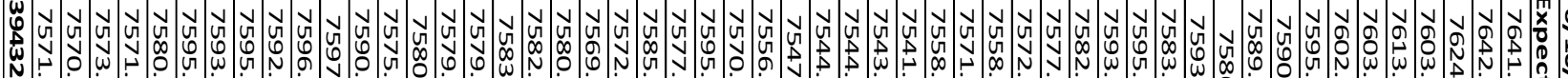

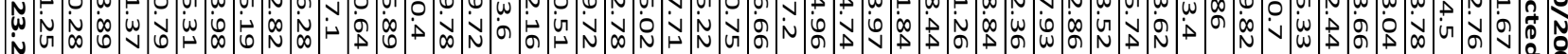

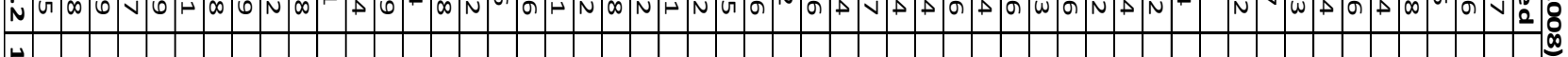

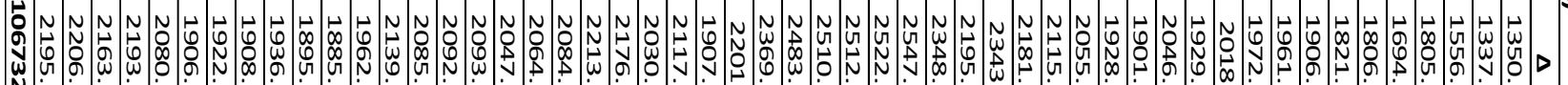

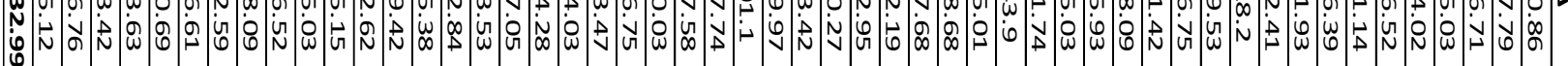

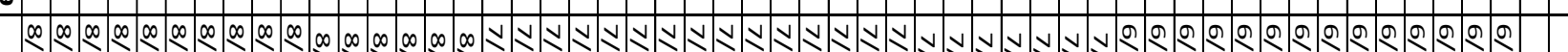

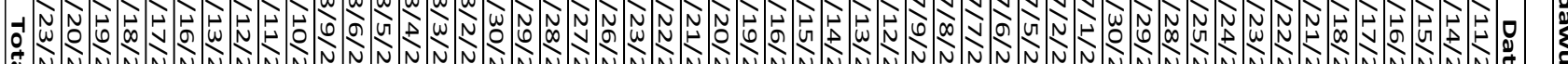

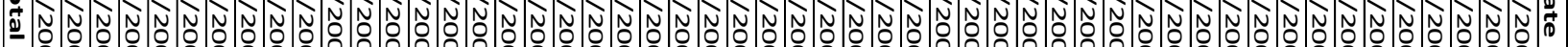

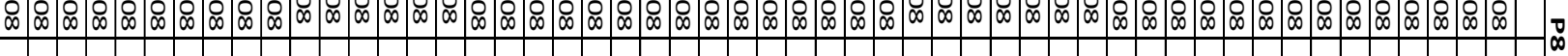

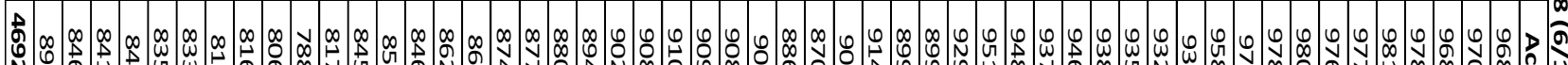

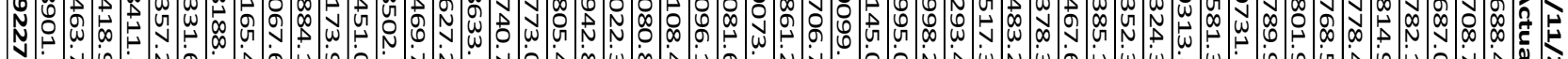

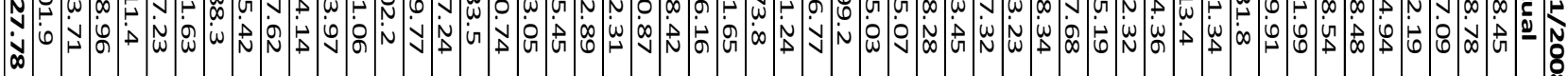

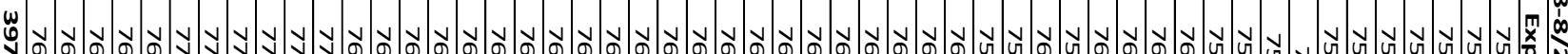

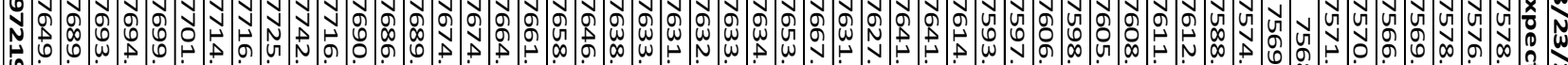

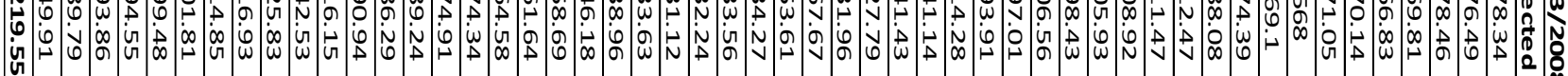

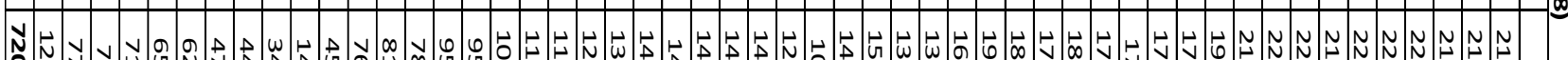

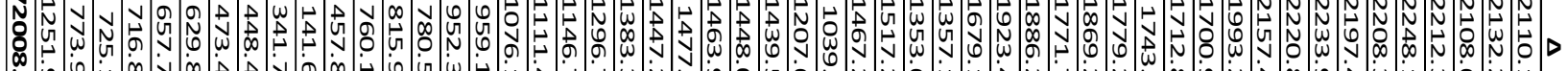

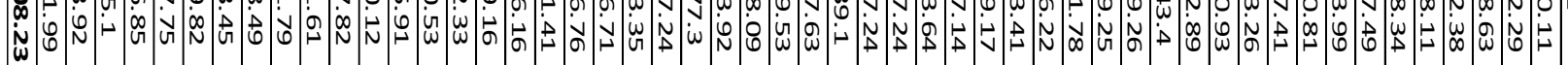

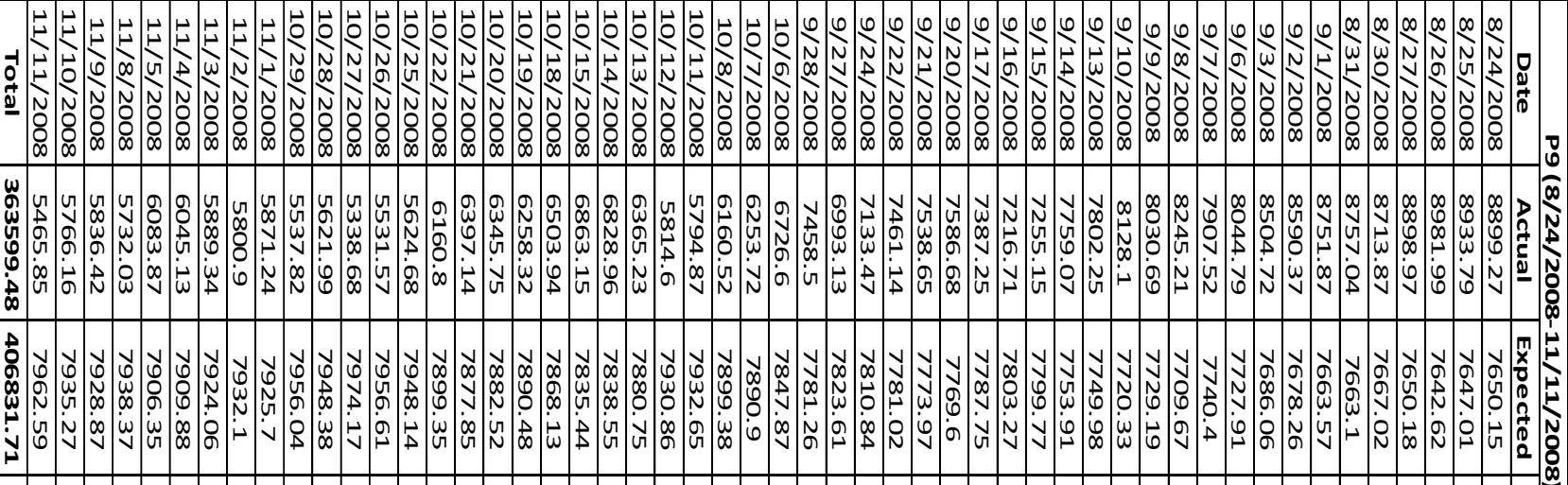

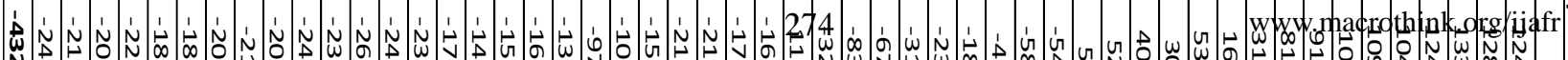

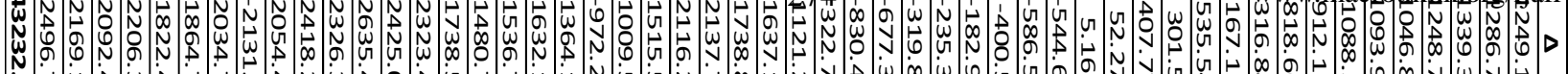

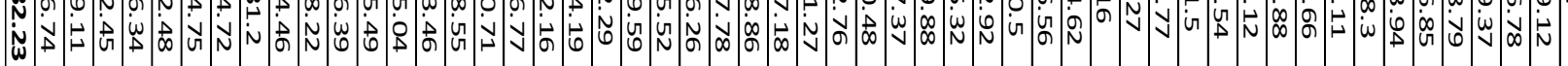


A. T-Statistics Results:

\begin{tabular}{|c|c|c|c|c|c|c|}
\hline \multicolumn{7}{|c|}{ T-statistics results } \\
\hline \multirow{3}{*}{ Data set } & \multicolumn{6}{|c|}{ Test Value $=0$} \\
\hline & \multirow[b]{2}{*}{$\mathbf{t}$} & \multirow[b]{2}{*}{ df } & \multirow[b]{2}{*}{ Sig. (2-tailed) } & \multirow{2}{*}{$\begin{array}{c}\text { Mean } \\
\text { Difference } \\
\end{array}$} & \multicolumn{2}{|c|}{$\begin{array}{c}95 \% \text { Confidence Interval of } \\
\text { the Difference }\end{array}$} \\
\hline & & & & & Lower & Upper \\
\hline $\mathrm{P} 1 \Delta$ & -.047 & 51 & .963 & -4.41365 & -193.0428 & 184.2155 \\
\hline $\mathrm{P} 2 \Delta$ & -.149 & 51 & .882 & -9.75231 & -140.7672 & 121.2626 \\
\hline $\mathrm{P} 3 \Delta$ & -14.415 & 51 & .000 & -501.69769 & -571.5693 & -431.8261 \\
\hline $\mathrm{P} 4 \Delta$ & 7.128 & 51 & .000 & 176.05654 & 126.4731 & 225.6400 \\
\hline $\mathrm{P} 5 \Delta$ & 16.183 & 51 & .000 & 2592.39692 & 2270.8003 & 2913.9936 \\
\hline $\mathrm{P} 6 \Delta$ & 29.129 & 51 & .000 & 1991.75288 & 1854.4793 & 2129.0265 \\
\hline $\mathrm{P} 7 \Delta$ & 57.807 & 51 & .000 & 2052.55750 & 1981.2746 & 2123.8404 \\
\hline $\mathrm{P} 8 \Delta$ & 16.939 & 51 & .000 & 1384.77365 & 1220.6503 & 1548.8970 \\
\hline $\mathrm{P9} \Delta$ & -4.779 & 51 & .000 & -831.38904 & -1180.6619 & -482.1162 \\
\hline
\end{tabular}

Table 5: T-statistics test results

A. Correlation Results:

\begin{tabular}{|c|c|c|c|c|c|c|}
\hline \multicolumn{7}{|c|}{ correlations } \\
\hline \multirow{2}{*}{ Data set } & \multirow{2}{*}{ Lag } & \multirow{2}{*}{ Correlation } & \multirow{2}{*}{ Std. Error ${ }^{a}$} & \multicolumn{3}{|c|}{ Box-Ljung Statistic } \\
\hline & & & & Value & df & Sig. \\
\hline $\mathrm{P} 1 \Delta$ & 1 & .954 & .135 & 50.110 & 1 & .000 \\
\hline $\mathrm{P} 2 \Delta$ & 1 & .864 & .135 & 41.120 & 1 & .000 \\
\hline $\mathrm{P} 3 \Delta$ & 1 & .907 & .135 & 45.260 & 1 & .000 \\
\hline $\mathrm{P} 4 \Delta$ & 1 & .824 & .135 & 37.339 & 1 & .000 \\
\hline P5 $\Delta$ & 1 & .950 & .135 & 49.699 & 1 & .000 \\
\hline $\mathrm{P} 6 \Delta$ & 1 & .693 & .135 & 26.461 & 1 & .000 \\
\hline $\mathrm{P} 7 \Delta$ & 1 & .828 & .135 & 37.722 & 1 & .000 \\
\hline $\mathrm{P} 8 \Delta$ & 1 & .950 & .135 & 49.734 & 1 & .000 \\
\hline $\mathrm{P9} \Delta$ & 1 & .928 & .135 & 47.418 & 1 & .000 \\
\hline \multicolumn{7}{|c|}{ a. The underlying process assumed is independence (white noise). } \\
\hline
\end{tabular}

Table 6: Correlation test results 


\section{Macrothink}

\section{A. Findings:}

The results are in favor of the efficiency theory. It can be suggested based on the stated results that the SSM has become informationally more efficient after the introduction of the "Tadawul" however; this "informationally efficiency" is decelerated by the slow reaction of investors. Based on the liner regression equations, the Cumulative Expected Returns (CAR) vary significantly from period to another (P1: 867.71, P2: -507.12, P3: -26088.28, P4: 9154.94, P5: 134804.64, P6: 103571.15, P7: 106732.99, P8: 72008.23, P9: -43232.23). Мy findings advocate Fama argument that analysis of the split between underreaction and overreaction is consistent with the efficiency hypothesis. The results of the t-statistics (shown in table 5) indicate a significant difference between the mean of the data sets taken at different periods of time which is coherent with the efficiency theory. The observed means were (P1: -0.047 , P2:-0.149, P3: -14.415, P4: 7.128, P5: 16.183, P6: 29.129, P7: 57.807, P8: 16.939, P9: -4.779). On the other hand, the slow adjustment to market information assumption also holds valid as a behavioral impact imposed on the market. Table 6 shows a fluctuation in the correlation of changes of returns over time suggesting a slow reaction to news by investors in the SSM. The correlation values (P1: 0.954, P2: 0.864, P3: 0.907, P4: 0.824, P5: 0.95, P6: 0.693, P7: 0.828, P8: 0.95, P9: 0928).

\section{Conclusion}

The SSM has become "informationally" more efficient after the formation of "Tadawul". The results support Fama anomalies split assumption and the slow adjustment to market information phenomena. In summary the SSM has a unique efficiency characteristic. First, it has emerged to become more efficient after the formation of "Tadawul". Second, its efficiency can be observed clearly via anomalies split. Third, this "efficiency" is slowed down by the investors' reaction to market information.

\section{References}

1. Fama, E. F. (1998) 'Market efficiency, Long-term returns, and Behavioral finance' Journal of Financial Economics 49(3):283-306

2. Hokroh, M. A. (2013) 'An Application of the Weak Form of the Efficiency Hypothesis on the Saudi Arabia Stock Market after Tadawul' Asian Journal of Finance and Accounting, 5(1), 382-395 